\title{
APRESIASI SASTRA ISLAMI DI INDONESIA
}

\author{
Mulyono \\ Dosen Fakultas Tarbiyah, Universitas Islam Negeri (UIN) Malang. \\ Jalan Gajayana No. 50 Telepon (0341) 551354, Faksimile (0341) 572533 Malang 65144
}

\begin{abstract}
The current situation of Islamic literature in Indonesia shows significant and important development in relation to testhelic, thematic, market, society, publising industry and literary writing. This trend shows that Islamic literature in Indonesia groun well and covers wide readers from various levels. Literary apprecation from society especially from academic members of PTAI (Islamic Higher Education Institution) is needed to make Islamic literature exits quantitatively and qualitatively. The development of Islamic literature is integral part of Islamic civilization development.
\end{abstract}

\section{Key words}

Islamic literature, Appreciation, Indonesia

\section{Pendahuluan}

Harus diakui, kehidupan sastra Islami Indonesia dewasa ini mengalami perkembangan yang sangat pesat. Sebagai bukti, dunia fiksi bernafaskan Islam sedang membanjiri dunia penerbitan dan penulisan di negeri ini. Dari segi jumlah, setiap bulannya selalu muncul nama baru yang menerbitkan karya dalam bentuk buku atau di media Islam, sementara penulis senior makin mantap berkarya, sedang penulis yunior terus bermunculan setiap saat.

Penerbitan pun semakin menjamur, para penerbit yang lebih dahulu berkiprah juga tak mau kalah, sedang penerbit baru juga terus 
bermunculan di berbagai kota di seluruh Indonesia. Semuanya saling berlomba untuk menerbitkan buku-buku fiksi Islami yang saat ini sedang digandrungi oleh masyarakat, mengingat isi buku-buku sastra tersebut tidak sekedar pelipur lara di kala duka, namun dapat lebih mencerahkan jiwa masyarakat pembacanya khususnya dalam meningkatkan wawasan, pemahaman dan keyakinan terhadap kehidupan beragama. Sehingga setiap ada pameran atau festival buku nasional, buku-buku fiksi Islami menyebar dan hadir di mana-mana.

Dari segi prestasi, buku fiksi Islami nyaris selalu mendapat tempat sebagai pemenang dalam ajang Adhi Karya IKAPI yang tiap tahun diadakan, baik untuk penulis, perwajahan, maupun kategori lainnya. Buku remaja terbaik nasional tahun 2001 adalah Rembulan di Mata Ibu, sedangkan Dialog Dua Layar menjadi satu dari 3 buku remaja terbaik Adhi Karya IKAPI tahun 2002. Kedua buku itu diterbitkan oleh penerbit Islam. Karya Helvy Tiana Rosa berjudul "Jaring-jaring Merah" malah dinobatkan sebagai 10 cerpen terbaik dalam 10 tahun versi Majalah Horison (Suhermanto, 2006:10).

Faktor kejenuhan pembaca buku fiksi terhadap tulisan atau karya yang tidak memberikan pencerahan secara ruhiyah yang bersumber pada nilai-nilai religiusitas -dan hanya menonjolkan nilainilai perasaan yang dibumbui dengan nafsu dan hedonisme belakasebagaimana ditemukan banyak karya fiksi era 1970 s.d 1990-an, mendorong para pengemar sastra untuk mencari buku-buku fiksi yang lebih berbobot yaitu sastra religius (Islami). Di samping itu, peningkatan pemahaman masyarakat terhadap Islam yang membuat mereka mencari novel atau cerpen yang "sehat" untuk peningkatan pemahaman keberagamaan mereka sekaligus mengandung hiburan. Para penulis sastra, seperti Gola Gong juga merasa jenuh dengan tema yang berkisar pada cinta dan seksualitas, mengingat beberapa penulis sastra tersebut seringkali lebih mengagungkan estetika dan melupakan fungsi sosialnya sebagai penulis.

Hadirnya film/senetron bertema religius (Islam) seperti yang sekarang sedang marak di berbagai stasiun TV juga akan saling 
melengkapi arti penting perkembangan seni Islam termasuk sastra. Misalnya tema/judul senetron tersebut: Insyaf ditayangkan jam 19.0020.00 WIB dan Hidayah jam 20.00-21.00 WIB di Trans TV; Maha Kasih dari Kisah-kisah Special Wisata Hati (jam 20.00-21.00 WIB) dan Bunga Kasih Sayang di RCTI; Rahasia Ilahi dan Jalan Keadilan di TPI; Doa dan Anugerah (siang jam 13.00 WIB) dan Lindungi TitipanMu (19.00-20.00 WIB) serta Sulaiman (20.00-21.00 WIB) di Indosiar; Istighfar di SCTV; dan insyaalah akan terus disusul dengan tema/judul lain di berbagai stasiun TV tentunya akan semakin semarak dan melengkapi perkembangan seni Islam (Data hasil observasi penulis, Januari s.d Mei 2006). Mengingat dari karya-karya sastra baik berupa novel, roman, cerpen dan kisah maupun sejarah, cerita dalam film/senetron tersebut diangkat.

Karya sastra yang diangkat menjadi judul film/senetron seperti roman Siti Nurbaya dan Sengsara Membawa Nikmat (TVRI di tahun 1990an) yang mendapat respon begitu besar dari masyarakat Indonesia merupakan apresiasi tertinggi terhadap hasil karya sastra. Sehingga terjadi hubungan timbal balik antara karya sastra dengan dunia perfilman/senetron. Di mana semakin berbobot dan beragamnya karya sastra dari sisi tema, cerita dan setting juga akan semakin semarak pula dunia perfilman/senetron nasional.

Melihat berbagai realitas perkembangan sastra Islam di Indonesia dewasa ini sebagaimana dipaparkan di atas, penulis ingin mengkaji lebih mendalam tentang: bagaimana apresiasi sastra Islami Indonesia terkini? Dengan tujuan agar kita dapat lebih memahami tentang apresiasi sastra Islami Indonesia dewasa ini, sehingga dapat memotivasi para pembaca utamanya civitas akademika di lingkungan PTAI untuk memberikan apresiasi bahkan terdorong untuk menghasilkan karya sastra Islami tersebut sebagai bagian pengembangan peradaban Islam secara integratif.

\section{Apresiasi Sastra Islami}

Dalam Kamus Besar Bahasa Indonesia (2002: 62), apresiasi diartikan: 1) kesadaran terhadap nilai seni dan budaya, 2) penilaian (penghargaan) 
terhadap sesuatu, dan 3) kenaikan nilai barang karena harga pasarnya naik atau permintaan akan barang itu bertambah. Berapresiasi artinya melakukan pengamatan, penilaian, dan penghargaan, misalnya sesuai dengan pembahasan ini adalah apresiasi sastra Islami.

Sedang sastra dalam Kamus Besar Bahasa Indonesia (2002:10011002), diartikan: 1) bahasa (kata-kata, gaya bahasa) yang dipakai di kitab-kitab (bukan bahasa sehari-hari), 2) kesusastraan, 3) kitab suci Hindu, kitab ilmu pengetahuan, 4) kitab, pustaka, primbon (berisi ramalan, hitungan, dsb., 5) tulisan; huruf.

Jika memakai rumus terminologi susastra maka akan didapati su sebagai jiwa yang akan tampil pada sastra. Su adalah keindahan atau estetika atau bisa dikatakan kata-kata yang baik dan nasihat-nasihat, sedangkan sastra adalah huruf, abjad atau yang melafalkan $s u$ tersebut. Dalam pengertian yang sederhana, maka dapat kita pahami bahwa sastra mempunyai dua unsur pokok, yaitu yang pertama sastra sebagai jiwa serta isi (ruh) yang berupa gagasan atau ide penulis, umumnya dilandasi dengan nilai-nilai filosofis maupun religius, dan yang kedua sebagai jasad atau wadah dari jiwa serta isi (ruh) sastra yang berupa tema, tokoh cerita baik sebagai pemeran utama maupun sampingan, alur cerita, setting, adegan, maupun ungkapan yang dipakai para pelaku cerita.

Penggunaan kalimat sastra Islami sesungguhnya tidak jadi persoalan, karena ia tidak masuk ke esensi su sastra itu. Ia hanya penamaan atau tanda dari luar. Hingga sekarang ini memang masih terjadi polemik tentang istilah sastra Islami. Sebagian sastrawan menyetujui tentang penamaan sastra Islami, dengan alasan bahwa sastra itu mempunyai kandungan dengan nilai Islam. Adapula yang tidak menyetujui tentang istilah sastra Islami, karena mereka menganggap bahwa apabila sastra diberi baju Islam bukankah justru membatasi ruang dan gerak sastra itu sendiri. Namun kita sepakat bahwa sastra Islami adalah sebuah sastra yang bersifat Islami. Dalam banyak hal, realitas karya sastra Islami tersebut seperti dicontohkan pada kisahkisah di Al-Qur'an, cerita-cerita dari Nabi saw., maupun biografi dan 
hasil karya sastra para sufi dan sastrawan Islam tempo dulu seperti Seribu Sastu Malam dan cerita-cerita menarik dari Abu Nawas.

Dengan pengertian di atas, maka apresiasi sastra Islami dapat diartikan sebagai kedasaran akan nilai-nilai sastra Islami. Kesadaran yang dimaksud meliputi pemahaman, penghayatan, dan kemampuan untuk menghargai karya sastra Islami (Sulistyio, 2005:7).

Ada dua hal terpenting dalam kegiatan apresiasi yang dapat dilakukan sesorang, yakni: Pertama, menanggapi/menginterpretasi karya sastra Islami yang bermutu. Menanggapi/menginterpretasi karya sastra Islami berarti memberikan komentar tentang baik dan buruknya terhadap hasil karya sastra dan mencoba menterjemahkan bagaimana karya sastra tersebut. Lewat kegiatan ini masyarakat (pembaca) akan menjelaskan lebih lanjut, artinya mereka memberikan penilaian baik atau tidaknya terhadap hasil karya sastra yang dibacanya atau penilaian itu berdasarkan kajian lebih mendalam melalui analisis terhadap unsurunsur karya sastra Islami, misalnya penilaian terhadap: 1) bagaimana struktur fisik sastra yang meliputi: alur, latar dan tokoh, 2) bagaimana struktur tematik sastra meliputi: tema dan amanat, dan 3) bagaimana struktur retorik sastra meliputi: diksi, majas dan sudut pandang.

Kedua, Berkarya sesuai dengan jenis kegiatan yang dipilih. Dilihat dari bentuknya, karya sastra Islami terbagi menjadi dua, yaitu puisi dan prosa. Puisi dibagi lagi menjadi: syair, pantun, gurindam dua belas, soneta, puisi bebas dll; sedang prosa dibagi menjadi: dongeng, hikayat, biografi, roman, novel, cerpen, cerbung dll. Dari sekian jenis prosa yang paling popular saat ini adalah cerpen dan novel. Dari berbagai bentuk dan jenis karya sastra tersebut, masyarakat (pembaca) khususnya civitas akademika perguruan tinggi Islam dapat mencoba/membuat karya sastra Islami dengan jalan memilih sebagian dari jenis-jenis karya sastra tersebut yang paling disenangi dan dikuasainya. Dalam memilih sebagian jenis karya sastra dapat diarahkan antara lain dalam pemilihan tema, judul, setting, pelaku cerita, alur penceritaan dan sebagainya; yang sesuai dengan pengalaman, pengetahuan, kecenderungan serta kemampuannya dalam 
menuangkan suatu ide/gagasan dalam bentuk karya sastra. Misalnya menyusun cerpen ataupun novel dengan judul: Kisah Cinta di Kampus, Cinta di Bilik Pesantren, Surau di Balik Bukit, Adzan Menggema, Gus dan Ning, Bersimpuh di HadapanMu Tuhan, Perjuangan Tiada Lelah, Kesabaran, Kejujuran, dan lain-lain.

\section{Sastra dan Agama}

Dalam tinjauan sejarah sastra dan agama zaman Romawi, barangkali bisa kita temukan dalam sejarah tersebut, sebuah bukti betapa nyata kedekatan sastra dengan agama. Novalis (1772-1801), penyair sekaligus filsuf Jerman berpendapat bila awalnya sastrawan dan pendeta itu satu. Dalam perkembangannya, kedua profesi itu terpecah sehingga ada istilah, seorang sastrawan yang asli, selalu seorang pendeta, juga seorang pendeta yang sungguhan, selalu juga seorang sastrawan. Sastrawan sebagai seorang peramal dan sebagai penemu karya seni yang diambil dari kehidupan nyata, kemudian diciptakan sendiri. Dengan demikian, dapat kita garis bawahi bahwa pendetapendeta itu juga bersastra lewat teater Khatolik dan teater Jesuit. (Masnunah, 2006:5).

Dalam literatur sastra Arab klasik atau sastra jahily tokoh-tokoh penyair ternama seperti Imru Al-Qays, Amru bin Kulsum, Al-Harist, Hatim Al-Tha 'i, Qays bin Mulawwih, Labid bin Rabi'ah, Tharfa bin 'Abd, dan Zuhair bin Salma. Yang membuat karya ini terasa tidak pernah mati citra rasanya sampai pada zaman kini, menurut Taha Husain dalam bukunya Fi al-Adab al-Jahili (Sastra Pra-Islam) adalah karena kekuatan estetikanya yang didukung keterpautannya dengan alam, penggambaran tentang gairah hidup, tanggung jawab, keabadian cinta, kesetiaan, pengorbanan, kepatuhan dan keteguhan mereka memegang kepercayaan.

Abu A'la al Ma`ary penulis Risalah al-Gufron, Komedia al Ilahiyah misalnya, sampai kini karyanya dianggap oleh Taha Husain dan pengikutnya seperti Jabir Asfoor sebagai Ayat al Adab al Araby simbol sastra Arab yang terkemuka, bahkan simbol liberalisme atau 
pembebasan sebuah karya karena dalam segi keindahan bahasanya tiada yang menandingi selain Al-Qur'an. Menurut Husain yang mempertahankan nilai sastranya adalah terletak pada kekuatan bahasanya atau estetikanya, selain memang di dalamnya penuh dengan kekayaan filsafat. Dengan tanpa maksud berdakwah, al Ma ary justru malah mengkritisi teks agama yang telah dianggap suci dan sakral yang sekian abad tidak boleh disentuh oleh pikiran manusia. Tak mengherankan karya ini kemudian disadur oleh sastrawan asal Italia, Dente Alighieri di abad ke-14 (1265-1321) dengan judul yang hampir sama The Divine Comedy-Paradise. Dante dan Ma'ary sama-sama mengkritisi hukum Tuhan dan agama.

Dante adalah sastrawan terkemuka di Italia. Selain Dante, di Inggris ada Shakespeare, di Spanyol ada Cervantes, di Jerman ada Goethe dan Sciller, di Prancis ada Balzac, di Rusia ada Destowjeksi dan Tolstoi. Di belahan Karibia, di sana bisa ditemukan Pablo Neruda dari Cile dan Marques dari Colombia yang karyanya mendunia, di samping sebagai penerima nobel sastra. Disusul Allendre dari Chile Paulo Coelho dari Brazil yang karya-karyanya banyak diterjemahkan ke dalam bahasa dunia. Di Pakistan ada Muhammad Iqbal, di Mesir ada Mutanabi, di Lebanon ada Khalil Gibran dan sebagainya.

Di Indonesia sejak tahun 1970-an hingga sekarang telah banyak lahir tokoh-tokoh sastrawan religius, seperti: Motingge Busye, Pramoedya Ananta Toer, YB. Mangunwijaya, Ajib Rosidi, Danarto, Sutarzy Calzoum Bachri, Kuntowijoyo, M. Fudholi Zaini, Muhammad Zuhri, KH. Mustofa Bisri, KH. Zawawi Imran, Emha Ainun Najib dengan karyanya kumpulan cerpen Slilit Kyai, Helvy Tiana Rosa, dan lain-lain. Sebenarnya, jauh sebelum menjamurnya penerbitan fiksi Islami dewasa ini, sejak zaman dahulu sudah banyak lahir karya-karya sastra Islami di Indonesia (Nusantara). Menurut Dadi dari Penerbit Senayan Abadi, karya yang paling menonjol adalah Tajussaalatin (Hamzah Fansury), Bustanussalatin (Nuruddin ar-Raniri), dan Gurindam Dua Belas (Raja Ali Haji). Saat itu, sastra Islami berkembang pesat. Ini dapat dilihat dari peninggalan Kerajaan Perlak hingga Ternate dan Sasak. Abad ke-19 mulai muncul lagi dengan lahirnya karya-karya dari 
Abdullah bin Abdul Kadir Munsyi, kemudian awal abad ke-20 dengan lahirnya karya-karya Amir Hamzah. Pada zaman pasca-kemerdekaan, lahir karya-karya Hamka dengan Tenggelamnya Kapal van Der Wijk dan Di Bawah Lindungan Ka'bah. Tetapi, sepertinya, tidak ada yang membanjir seperti yang terjadi dalam 10 tahun belakangan, dan sepertinya masih saja terus melonjak. (Suhermanto, 2006:10).

\section{Perkembangan Apresiasi Sastra}

Perkembangan pesat terhadap apresiasi sastra Islami dewasa ini dapat dilihat beberapa kecenderungan yang ada. Pertama, semakin beragamnya bentuk karya sastra Islam yang hadir saat ini baik berupa cerpen, novel, kisah maupun drama. Sekaligus semakin beragamnya tema-tema dan alur cerita yang digarap. Hal ini berangkat dari semakin terpelajarnya umat Islam Indonesia dan semakin beragam pula latar belakang kehidupan, asal daerah, pendidikan, organisasi, pengalaman dan sudut pandang dari para penciptanya. Sehingga keanekaragaman para penulis tersebut sangat berpengaruh terhadap corak dan keanekaragaman karya-karya sastra Islami Indonesia dewasa ini.

Kedua, yang sangat penting bagi pertumbuhan dan perkembangan sastra Islami Indonesia terkini adalah pertumbuhan pasar yang begitu pesat dan menggembirakan. Kecenderungan ini ditandai dengan larisnya buku-buku Islami termasuk buku-buku karya sastra baik itu novel, cerita/kisah, maupun kumpulan puisi dan cerpen. Tidak hanya buku-buku kumpulan sastra dalam kelompok fiksi Islami seperti karya-karya Asma Nadia dan Pipiet Senja, atau jenis chicklit dan teenlit, yang laris di pasar; tetapi juga buku-buku sastra dengan kajian yang serius, seperti buku-buku kumpulan cerpen karya-karya Seno Gumira Ajidarma, Jenar Maesa Ayu, Kurnia Effendi, dan Yanusa Nugroho (Ahmadun, 2006:4).

Ketiga, Kecenderungan tersebut diikuti dengan makin banyaknya industri penerbitan yang menggarap buku-buku sastra. Setelah dalam beberapa dasawarsa mendapat tempat terhormat di media massa cetak, sastra kini mendapat perhatian serius dalam 
industri penerbitan. Saat ini hampir semua penerbit di Indonesia termasuk yang semula tidak memiliki divisi penerbitan karya fiksi (sastra), seperti Mizan, Republika, Rajawali, dan Obor - ikut merambah pasar buku fiksi (sastra). (Ahmadun, 2006:4).

Keempat, Maraknya penerbitan buku sastra khususnya kumpulan cerpen dan novel, tidak terlepas dari peran jaringan dan komunitas penulis yang menamakan diri Forum Lingkar Pena (FLP). Komunitas yang lahir pada 1994 ini menyadarkan para penulis fiksi (sastra) dan pengelola penerbitan bahwa potensi pasar fiksi di Indonesia ternyata begitu besar dan luas. Satu contoh, majalah khusus cerpen yang ikut melahirkan para penulis FLP, yakni Annida, bisa mencapai oplah yang begitu tinggi, yakni 70 ribu eksemplar. Sementara buku-buku kumpulan cerpen terbitan FLP selalu terjual habis tidak lama setelah diterbitkan. Tentu, anggota FLP saat ini (2006) yang mencapai 5000 orang lebih menjadi pasar utama buku-buku kumpulan cerpen terbitan FLP, selain masyarakat umum penggemar fiksi (sastra) Islami. (Ahmadun, 2006:4).

Kelima, Realitas pasar buku fiksi yang memiliki bobot sastra dan bertema Islami yang dibuka oleh FLP itu menarik minat para penerbit besar-komersial (pengusaha penerbitan), seperti Gramedia dan Mizan, untuk menggarap pasar yang sama. Kenyataannya, buku-buku fiksi karya Asma Nadia, yang mereka terbitkan, mengalami cetak ulang berkali-kali dan mencapai best seller. Dalam tahun 2003, novel Cinta Tak Pernah Menari (Gramedia, 2003), misalnya, mengalami cetak ulang tiga kali hanya dalam dua pekan, dan novelnya, Rembulan di Mata Ibu (Mizan, 2001), mengalami cetak ulang hingga delapan kali.

Predikat best seller juga diraih novel Kapas-kapas di Langit (Zikrul Hakim) karya Pipiet Senja. Terakhir, novel Ayat-ayat Cinta (Republika, 2005) karya Habiburrahman El Siraji, sudah cetak ulang 12 kali hanya dalam waktu sekitar satu tahun, sehingga mencapai predikat best seller, dengan pemasukan kotor (bruto) Rp. 3 milliar lebih bagi penerbitnya. (Yosi, 2006).

Keenam, Maraknya film/senetron bertema religius (Islam) seperti yang ditayangkan di berbagai stasiun TV pada jam-jam penting (18.00 - 
22.00 WIB) juga akan menjadi pendorong utama arti penting perkembangan seni Islam termasuk sastra. Senetron religius misalnya tema Hidayah yang ditayangkan jam 20.00-21.00 WIB di Trans TV didukung oleh iklan sekitar 15 macam. Hal ini melebihi jumlah iklan pada tayangan senetron Tutur Tinular (1999-2002), Angleng Darma, Misteri Gunung Merapi di Indosiar atau bahkan melebihi kejayaan Ketoprak Humor di RCTI (1999-2003). Hal ini menunjukkan bahwa senetron Islam mendapat apresiasi yang begitu besar baik dari pemirsa di berbagai lapisan masyarakat maupun berbagai perusahaan sebagai sponsor. Bahkan beberapa kisah yang diangkat dari kisah-kisah nyata dari Malaysia menunjukkan bahwa senetron Islami juga disenangi oleh penonton di negeri Malaysia maupun Brunai Darussalam. Senetron Islami sekarang juga mampu bersaing dengan senetron konvensional yang lebih sering mengambil tema tentang: cinta, keretakan keluarga (seperti Tersanjung di Indosiar), takhayul dan horor maupun ceritacerita rakyat seperti Jaka Tingkir, Jaka Tarub, dll. Tentu saja hadirnya film/senetron Islami tersebut agar tetap eksis dan semakin berbobot, maka perlu didukung dengan karya-karya sastra Islami yang berbobot dan beragam sebagai sumber cerita (penulisan skenario).

Di luar mainstream sastra Islam, buku-buku sastra baik novel maupun cerpen umum (tema cinta dan seksual), seperti karya-karya Ayu Utami (Saman dan Larung) serta Djenar Maesa Ayu (Mereka Bilang Aku Monyet dan Jangan Main-main dengan Kelaminmu) juga mengalami cetak ulang berkali-kali. Fiksi-fiksi seksual mereka itu, bersama karya Dinar Rahayu (Sebuah Ode Buat Leapol), bahkan sempat disebut-sebut membawa sebagai fenomena baru bagi sastra Indonesia sehingga banyak didiskusikan dan mengundang kontroversi. Karya-karya mereka sempat mempengaruhi sejumlah penulis lain, seperti Hudan Hidayat (Keluarga Gila serta Tuan dan Nona Kosong), untuk bersikap terbuka dalam menggambarkan masalah-masalah seksual. (Yosi, 2006). Karya sastra yang bertema seksual semata umumnya bersifat musiman, karena orang mudah berubah selera. Sedang karya-karya sastra Islami walaupun boleh jadi sebagian cerita mengandung kisah percintaan tetapi kalau ada nilai-nilai ideology, moral dan kemanusiaan maka akan 
tetap menjadi sastra yang berbobot dan lebih bersifat abadi, misalnya roman Siti Nurbaya, Tenggelamnya Kapal wan Der Wijk, Di Bawah Lindungan Ka'bah maupun Atheis.

\section{Penutup}

Karya sastra adalah representasi dan manifestasi atas pemikiran dan ideologi penciptanya (sastrawan) yang disampaikan dengan media bahasa dan mempunyai nilai etika dan estetika yang dominan. Karena itu, karya sastra pada hakekatnya merupakan suatu dunia (dunia dalam kata - menurut istilah Chairil Anwar) yaitu dunia yang dibentuk oleh penciptanya.

Sebagai dunia karya sastra selalu menyuguhkan miniatur realitas yang simbolik, memotret sebuah dunia atau pemikiran berdasarkan cara yang khas sesuai dengan cara pandang penciptanya. Dipahami oleh banyak orang bahwa dalam dunia sastra itu selalu ada etika dan estetika. Banyak orang memaknai etika atau moral dan estetika sebagai nilai keindahan dalam sastra. Nilai etika atau moral dalam sastra yang baik haruslah karya sastra yang memberikan wawasan terhadap pencerahan pemikiran dan ruhiyah serta mendidik, mempunyai etika terhadap perkembangan perilaku pembacanya. Islam sebagai sumber pedoman hidup (way of life) tentunya merupakan sumber etika dan estetika yang tiada habis-habisnya digali, dan realitas kehidupan khususnya kehidupan beragama di Indonesia yang multikultural merupakan sumber kisah yang tak habis-habisnya.Maka dari itu berlandaskan pada Al-Qur'an dan Hadits serta menyimak realitas kehidupan keberagamaan di Indonesia merupakan sumber penulisan karya sastra yang tak akan kering. Untuk menumbuhkembangkan semangat penulisan karya sastra Islami yang bersumber dari dari dalil naqli dan aqli serta realitas kehidupan (kauniyah) tersebut perlu adanya apresiasi sastra. Artikel singkat ini nampaknya mendorong kita semua bagaimana seyogyanya kita mampu memberikan apresiasi sastra Islami dengan baik, sebagai bagian penting terhadap pengembangan peradaan Islam secara integratif. $\square$ 


\section{DAFTAR PUSTAKA}

Ahmadun, Yosi Herfanda. 2006, 21 Mei. Cerpen Peta Perkembangan Indonesia Terkini. Republika.

Departemen Pendidikan dan Kebudayaan. 2002. Kamus Besar Bahasa Indonesia. Jakarta: Balai Pustaka.

Masnunah, Dewi dan Syamsiah. 2006. Teori dan Praktek Sastra Islami. Makalah Pendidikan Seni Religius. Dosen: Mulyono, MA. Malang: Jurusan Pendidikan Fakultas Tarbiyah Islam UIN Malang. 
Nur'aini, dan Dliya'ul Firdausi. 2006. Seni Sastra Puisi Islam. Makalah Pendidikan Seni Religius. Dosen: Mulyono, MA. Malang: Jurusan Pendidikan Fakultas Tarbiyah Islam UIN Malang.

Suhermanto, Bambang dan Lailatus Salamah. 2006. Teori dan Perkembangan Seni Religius. Makalah Pendidikan Seni Religius. Dosen: Mulyono, MA. Malang: Jurusan Pendidikan Fakultas Tarbiyah Islam UIN Malang.

Sulistyo, H. Edy Tri. 2005. Kaji Dini Pendidikan Seni. Surakarta: Lembaga Pengembangan Pendidikan (LPP) UNS dan UPT Penerbitan dan Percetakan UNS (UNS Press). Cetakan 1.

Wulandari, Lia 2006. Seni Sastra Puisi. Makalah Pendidikan Seni Religius. Dosen: Mulyono, MA. Malang: Jurusan Pendidikan Fakultas Tarbiyah Islam UIN Malang.

Zilfa, Rohil dan Arif, 2006. Teori dan Praktek Seni Sastra Islam. Makalah Pendidikan Seni Religius. Dosen: Mulyono, MA. Malang: Jurusan Pendidikan Fakultas Tarbiyah Islam UIN Malang

http:// www.pusat-bahasa.depdiknas.go.id/showpenuh.

http:// www.wikipedia.com//

http:// www.pikiran-rakyat.com/cetak/1103/06/khazanah/lainnya01.hlm. 